\author{
Hugo de Oliveira Guimarães \\ da Silva \\ Mariana Cristina Magalhães \\ Costa \\ Maria Victoria Cabrera \\ Aguilera \\ Maria da Glória Diniz \\ de Almeida \\ Bernardo Bastos da Fonseca \\ José Salvador da Motta Reis \\ Luís César Ferreira Motta \\ Barbosa \\ Gilberto Santos ${ }^{1}$ \\ Nilo Antonio de Souza Sampaio
}

Article info:

Received 28.03.2021

Accepted 05.07.2021

UDC - 005.6

DOI - 10.24874/IJQR15.04-14

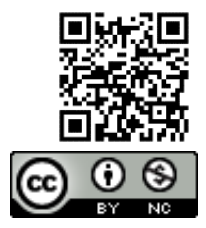

\section{IMPROVED VEHICLE PAINTING PROCESS USING STATISTICAL PROCESS CONTROL TOOLS IN AN AUTOMOBILE INDUSTRY}

Abstract: This abstract presents a case study approach based on qualitative methods and data that aimed a detailed examination of an environment, a particular subject or situation. The objective of this work is to improve the painting process of an automotive company through the application of Statistical Process Control for the optimization of performance indicators quality and productivity. Statistical Process Control is applied to the monitoring of manufacturing industry processes, including automotive manufacturing. The implementation of the SPC in production environments is to improve and control real-time product and process characteristics, quality and productivity is an accepted manufacturing event.

Keywords: Statistical process control; Quality Tools; Capability; Assembly Line; Quality Management.

\section{Introduction}

The manufacturing industry deals with different challenges to manage complexity in the production process due to a requirement for product diversity offered to customers (Chan \& Wu, 2002; Prashar, 2018; Santos, Murmura \& Bravi, 2019; Félix et al., 2019b; Barbosa et al., 2020). This scenario is common in the automotive industry, especially in truck manufacturing, where the combination of different accessories, details, colors and technical specifications available to consumers results in a higher quantity than light car manufacturing.
In this context, the automotive industry aims to reduce production time and cost, which influence the project decisions regarding the quality aspects that can guarantee manufacturing results and variations (Félix et al., 2019a; Azevedo et al., 2019; Machado et al., 2019). On the other hand, these decisions can affect the perceived quality in a negative way, as well as the quality of the manufacturing (Stylidis, Madrid, Wickman, \& Söderberg, 2017). Quality can play an important role in the organization and influence its survival and competitiveness (Mehrafrooz \& Noorossana, 2011; Araújo et al., 2019; Costa et al., 2019;

1 Corresponding author: Gilberto Santos

Email: gsantos@ipca.pt 
Africano, Rodrigues \& Santos, 2019). In a competitive environment, organizations use management tools, such as, lean tools (Rodrigues et al., 2020; Santos et al., 2019a; Ribeiro et al., 2019; Rodrigues et al., 2019; Santos et al., 2020) and others (Vieira et al., 2019; Santos et al., 2019c; Zgodavova et al., 2020; Silva et al., 2020) that enable them to achieve products and processes with high quality, without harming the environment and employee welfare (Murmura, Bravi \& Santos, 2021; Santos et al., 2014). Therefore, companies implement different quality, environmental, occupational health and occupational safety management systems as a way to achieve these goals (Barbosa, de Oliveira, \& Santos, 2018; Nunhes, Motta Barbosa, \& de Oliveira, 2017; Santos, Mendes \& Barbosa, 2011; Carvalho, Santos \& Gonçalves, 2019; Santos et al.,2019b; Rebelo, Santos \& Silva, 2016).

One of the quality assessment techniques is the Statistical Process Control (SPC). The SPC was initially proposed by Walter Shewhart as a tool to assist the elimination of abnormal variations in processes by differentiating between the common causes and the random (special) causes. Problems arising from special causes are inevitable in any process. Through the interpretation of the control chart, a process can be controlled and the common causes can be eliminated, avoiding the continuation of the problem. The SPC can be used as a management analysis tool for the monitoring process of the flow from a sector. By monitoring the flow, it is possible to estimate the losses in a study region. The causes of loss can be due to special causes or common causes which the SPC helps to manage (Capizzi, 2015; Tsung, Zhang, Cheng, \& Song, 2018).

The SPC is composed of a set of techniques and statistical tools, organized to provide, through their application, the maintenance and improvement of the quality levels of a process. It can be considered as a tool or as a strategy of the quality process among the many existing processes, being one of the ways to achieve some important results for an organization. Applying the SPC processes can be evaluated and waste can be reduced through the constant process evaluation (Tsung et al., 2018; Weusten \& Tummers, 2017).

This paper presents a case study approach based on qualitative methods and data that aimed a detailed examination of an environment, a particular subject or situation. The objective of this work is to improve the painting process of an automotive company located in the south of the State of Rio de Janeiro through the application of Statistical Process Control for the optimization of performance indicators regarding quality and productivity.

The relevance of this study is based on quality and statistical tools, among them process capability indices, theme that has been broadly studied and still widely applied in industrial processes that need to be understood and analyzed with its characteristics.

\section{Literature Background}

Statistical Process Control is applied to the monitoring of manufacturing industry processes, including automotive manufacturing. The implementation of the SPC in production environments is to improve and control real-time product and process characteristics, quality and productivity is an accepted manufacturing event (Rungtusanatham, 2001). Understanding the process structure and quantifying the process performance is essential for positive initiatives of quality improvement (Wagner et al., 2019; Wu, Pearn, \& Kotz, 2009; Bravi, Murmura \& Santos, 2019a; Jimenez et al., 2019; Sá et al., 2020).

According to Montgomery, (2017), statistical process control is a useful problem-solving toolkit to achieve process stability and increase capability by reducing variability. The SPC has a focus on conducting and 
maintaining the process in a stable state of operating conditions, always close to the desired goal (Tsung et al., 2018). Process capability studies are used to monitor the capacity of a process. To get a picture of the process capability, conditions need to be stable when the data is collected. Then the data can be evaluated in different ways, including the use of process capability indices (Deleryd, 1999).

Process Capability Indices (PCI) are applied to quantify the process performance, in order to meet the required specification limits. In particular, $\mathrm{C}_{\mathrm{p}}$ was the first index proposed in the engineering literature and used to assess the simple precision index considering the overall variability related to the manufacturing tolerance as a measure of process precision. $\mathrm{C}_{\mathrm{a}}$, mentioned as an accuracy index, a function of the process means and the specification limits conditioned to measure the degree of process centering relative to the manufacturing tolerance (Liu \& Li, 2020; Rasay, Naderkhani, \& Golmohammadi, 2020; White, Szarka, Childress, \& Jensen, 2020). The $\mathrm{C}_{\mathrm{pk}}$, aims to measure the distance between the specification limit closest to the expected value from the quality characteristic studied in order to relate half this distance to the amplitude of the natural process, $3 \sigma$. It considers both the magnitude of the process variance and the process departure according to the midpoint $\mathrm{m}$ in consideration. The $\mathrm{C}_{\mathrm{pm}}$, is an alternative index to $C_{p}$ and considers, in addition to the process variation, the distance from the average in relation to the nominal value of the specification. It is applied to measure the ability of a process to cluster around the target, and reflects the degrees of process targeting. The index $\mathrm{C}_{\mathrm{pmk}}$ combines the features of the indices $\mathrm{C}_{\mathrm{p}}, \mathrm{C}_{\mathrm{pk}}$ and $\mathrm{C}_{\mathrm{pm}}$ (Liu \& Li, 2020; Weusten \& Tummers, 2017; White et al., 2020).

It is an index that refines the analysis alerting the user when the process variance increases and/or the process mean deviates from its target value. These indices provide numerical measurements of whether or not a manufacturing process is capable of meeting a production tolerance predetermined level. The concept of PCI is used to compare what the process should do with what the process really does. The specification range must reflect the product usability limits in order to the process control results in a high quality product. What the process actually does refers mainly to process variability - the lower the variability, the lower the proportion of items that fall outside tolerance limits level (Wu et al., 2009).

To apply the standard SPC, there are three requirements, a mature understanding of the process, an observable relevant quality characteristic with associated quality criteria, and a strategy to verify the quality criteria in the organization in real time (Escobar, Wincek, Chakraborty, \& Morales-Menendez, 2018). In this process, prevention through learning from past mistakes and failures is indispensable. When an error or failure occurs, the causes are sought and analyzed, to then take necessary measures and action to prevent future errors and failures. This is done by researching and eliminating the errors and failures made (Schippers, 1998).

\section{Research Method}

To address the study of this case it has been chosen an exploratory research (Yin, 2017) in order to comprehend the context, to analyze and be more familiarized with the problems identified in the company making it more explicit. The context of the case study is described in section 3.1 and 3.2 where it is possible to identify parameter of initial references using quality tools and statistical data of the problems to be solve among the framework delineated.

Known the real scenario of the painting process in the production line, in section 3.3, it is established the goals of performance and quality to be achieved. The problems encountered in the initial situation were treated with solutions methods resulting in a 
new situation that was deployed and analyzed with quality tools.

The validation of these solutions proposed occurred through the Statistical Process Control, which allow the comparison of the initial situation and the new situation by index values, exposed in section 4 and discussed in section 5 .

\subsection{Analysis of the Vehicle Cabin Painting Process}

The automotive company's painting process is divided into four different stages: chemical treatment of bare plate surface (E-coat painting), sealing of vehicle critical areas, anti-corrosive paint UVA and UVB lightning protection of bodywork and painting Surface coatings (Top-Coat). Surface treatments ensure the preservation of parts and structures, increasing resistance to atmospheric agents (moisture, sunlight, heat, cold), chemical agents (acids, bases, organic solutions), mechanical effects (wear, scratching, deformation), besides it gives an esthetic finishing effect and gain special physical properties (thermal and / or electrical insulation or conductivity, radiation coefficient) (Rungtusanatham, 2001).

The focus of this work at the painting process is the sealing step of the areas classified as critical because this step is related to a direct impact activity of the end customer product. Moreover, it is a process that requires operational skill because it has low automation with high manual activity rate.

The sealing step is performed by the caulking process, which consists of the application of a viscous mass (Figure 1) capable of inhibiting oxidation in plate bonding regions of the vehicle body. This application is performed by using a brush and thereafter the vehicle body goes to a greenhouse so that the applied product is "cured" at elevated temperatures (Figure 2). In this phase the viscous mass is stiffened, fulfilling its protective role.

The initial study scenario was based on a situation where the average of failure in the body caulking process was above 1 (one) per vehicle, which is the maximum value that a quality occurrence can represent in a vehicle. The result of this extrapolation generates increased rework activities, which can impact negatively the product quality and increases costs.

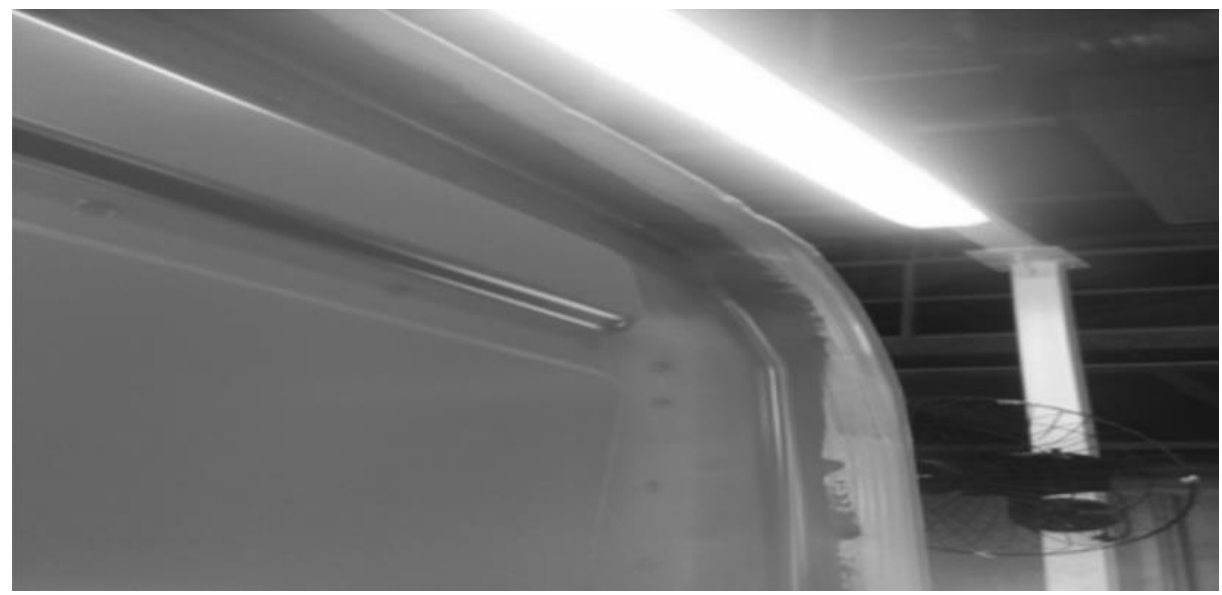

Figure 1. Viscous mass applied to the vehicle body 


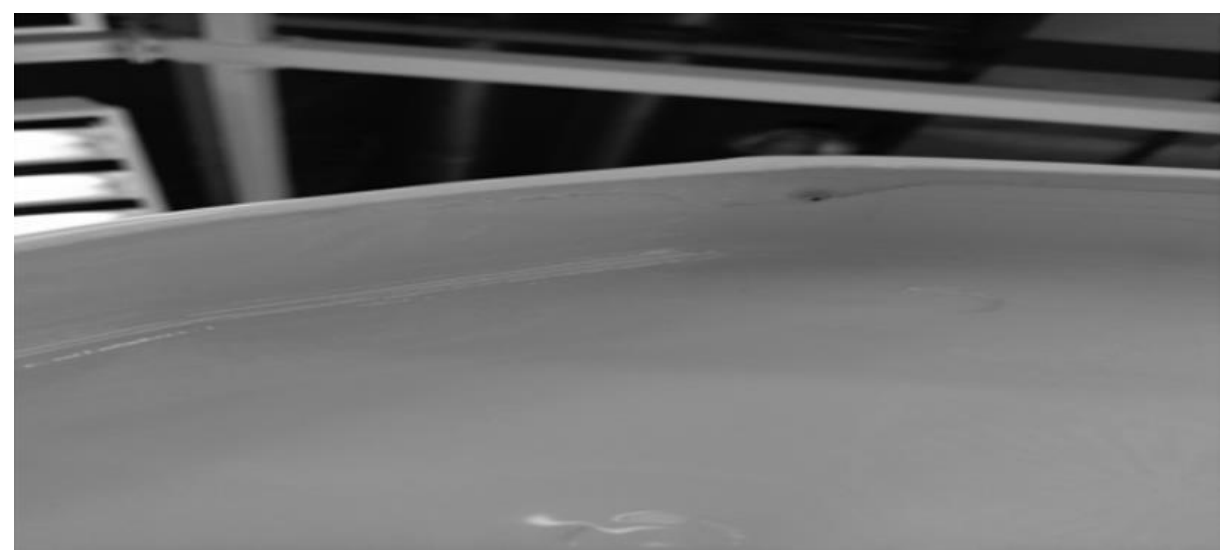

Figure 2. Viscous mass cured on the vehicle body

\subsection{Data Collection And Numerical Survey}

To measure the impact failures of the body caulking process data was collected from 40 days of work records and then we gathered the number of occurrences in the production process in order to stratify in a Pareto graph the impact that each occurrence generate in the production process.

For a better understanding of the losses in the production process, it was necessary for an additional stratification to show what body region was the center of quality problem as show in Figures 3 and 4.

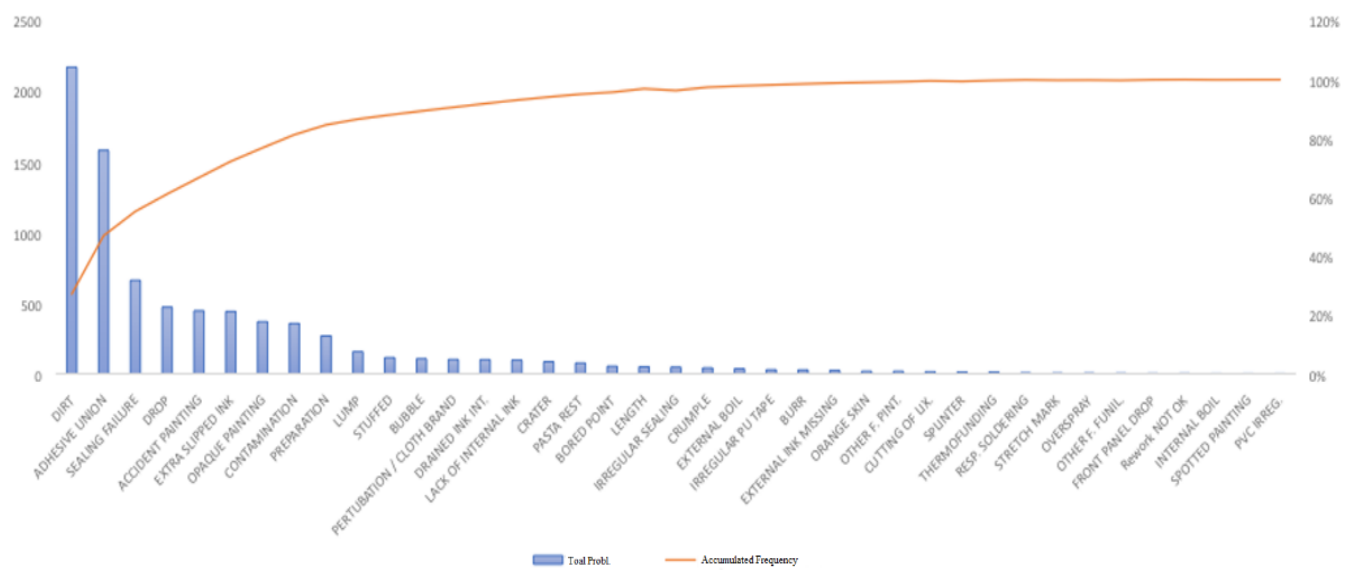

Figure 3. Quality problems stratification

The frequency of occurrences was ordered from the highest to the lowest, which allows the prioritization of problems, where $80 \%$ of the consequences come from $20 \%$ of the causes. It is possible to view and identify the most important problems, enabling the concentration of efforts.
The first occurrence shown in Figure 3 is assessed as a recurring factor and is addressed through the process of continuous improvement with the company's kaizen unit. The kaizen unit is responsible for receiving demands from the assembly line and developing immediate solutions. The second largest occurrence is directly related to the 
supplier process. The third, caulking failure, is the focus of the study and has an average of 1.13 occurrences per vehicle, higher than what the company considers satisfactory. These three occurrences together represent approximately $57 \%$ of the problems that occur in the painting process. The caulking failure has a direct impact on the satisfaction of the end customer and it alone represents approximately $25 \%$ of the problems.
The vehicle body is fragmented into regions called quadrants for easy viewing, design studies, and corrections in regions that have a defect. Each quadrant is the combination of letter (X-axis) and number (Y-axis). To show the impact in relation to the vehicle region, a complementary stratification by regions was performed using the Pareto diagram (Figures 4 and 5.

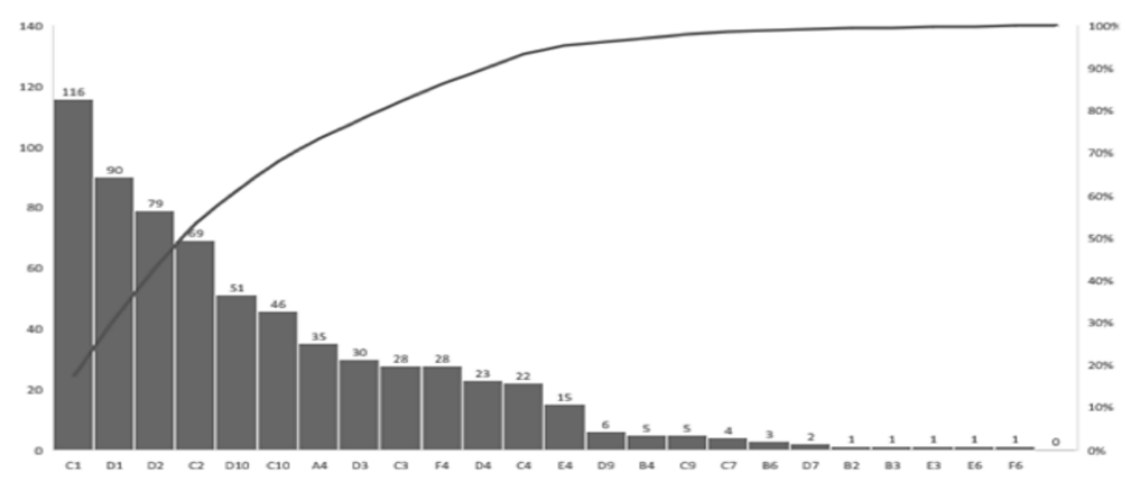

Figure 4. Vehicle region Stratification

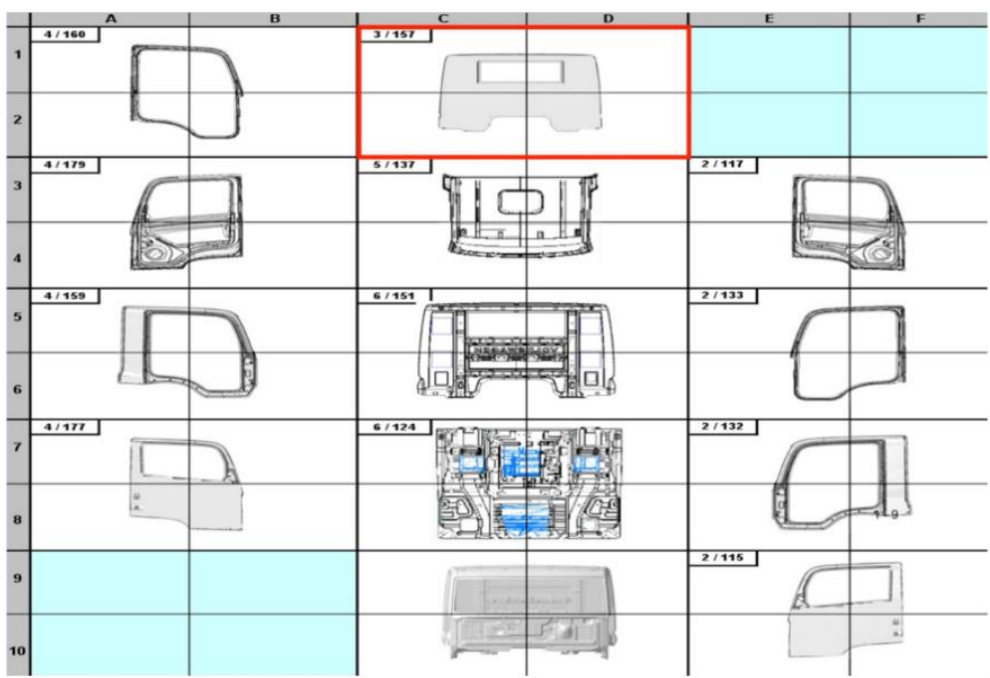

Figure 5. Most defective quadrants - rear panel of the vehicle cabin

The quadrants represented by a letter followed by a number refer to a region of the vehicle and the quadrants that added the greatest impact were C1, C2, D1, D2, which together represent approximately $53 \%$ of the problems (Figure 5). These quadrants represent the rear area of the vehicle body. Thus, the focus of actions to reduce the average occurrence will be in these four quadrants. 
Due to the occurrences in the selected quadrants and in order to propose improvements over those occurrences, a data collection plan based on 40 working days was developed to monitor the daily average of caulking failure. The monitoring values were collected at the workstation where the plate joints are caulked and inserted into a table in Microsoft Excel@ after being registered in the company's official control tool and recorded as shown in Figure 6. The $\mathrm{x}$-axis represent the days considered in the study and the y-axis represent the averages of caulking failures by day.

Over the data collection period, 28 days presented occurrences that exceeded the limit value of 1.00 occurrences per vehicle and the process oscillation at different amplitudes is high (Figure 7).

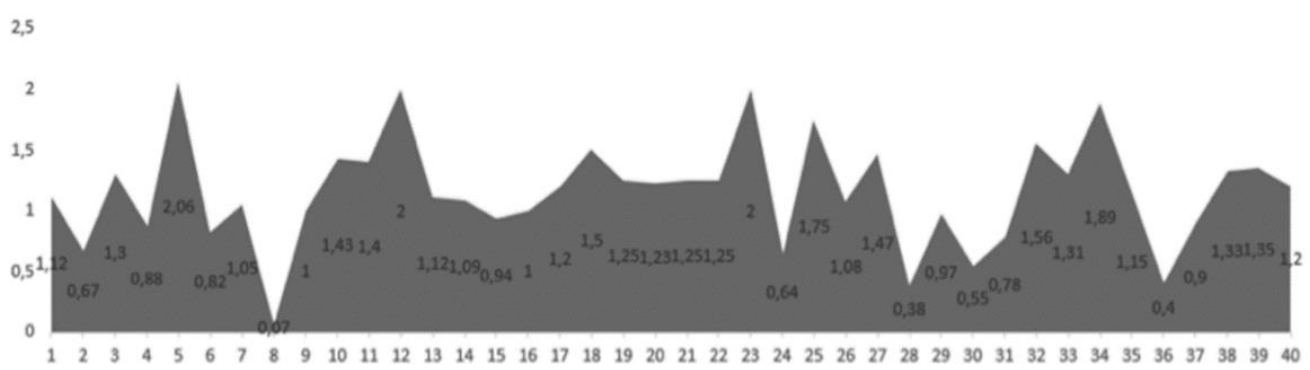

Figure 6. Daily average caulks failure

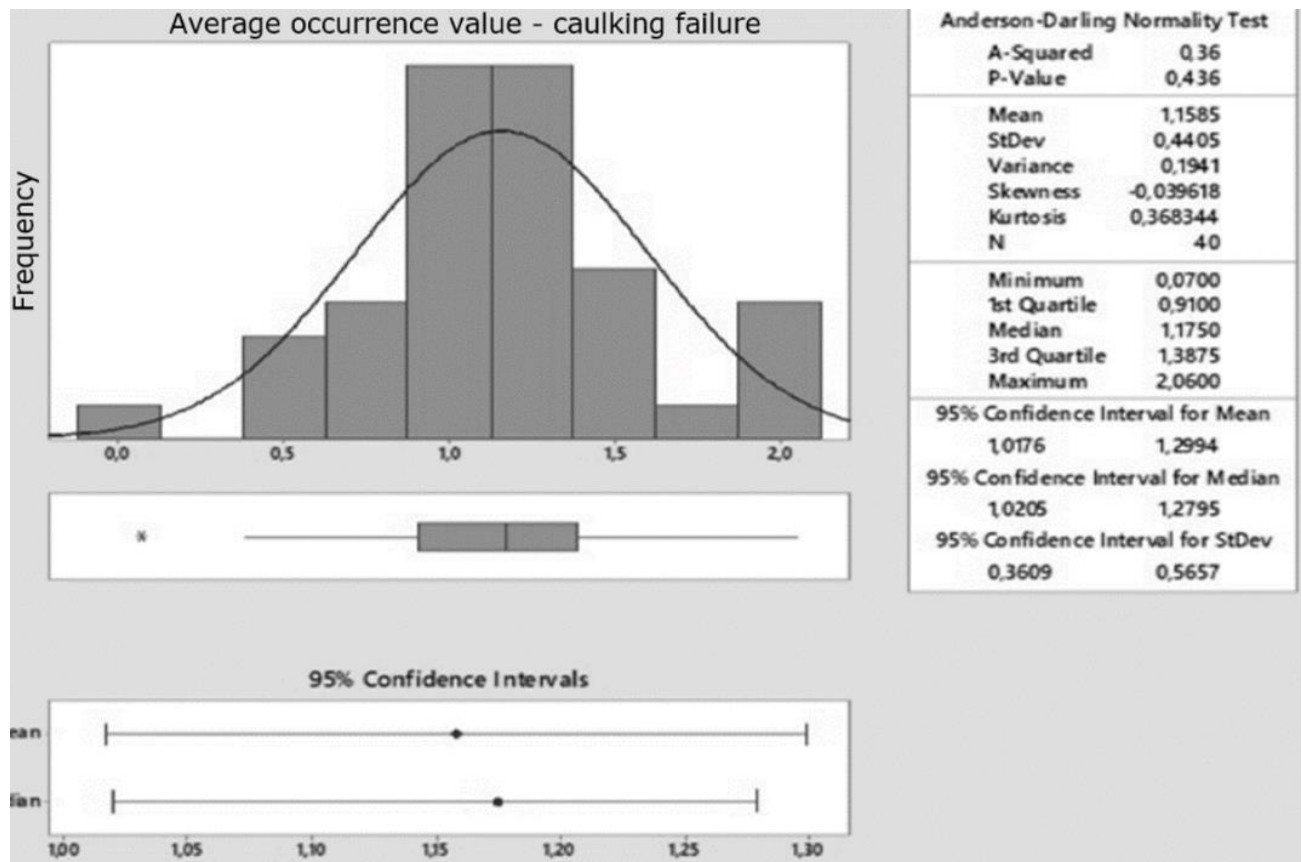

Figure 7. Initial Statistical Data - sample normality test

After the data collection period, the data was statistically interpreted in the MINITAB ${ }^{\circledR}$ software to obtain the starting values for sample normality, mean and standard deviation values (Figures 7 and 8), besides knowing the performance indices and process capability to subsequently measure process improvement. 
Figure 8 shows the dispersion of the sampled values where the average of occurrences is 1.159 occurrences per vehicle, the standard deviation of the process is 0.441 and the first and third quartiles values are 0.91 and 1.388 respectively. The values found are not in accordance with what the company establishes as ideal with the average value less than 1.00 occurrences per vehicle. Additionally, the initial results of the process capability were obtained as shown in Figure 9.

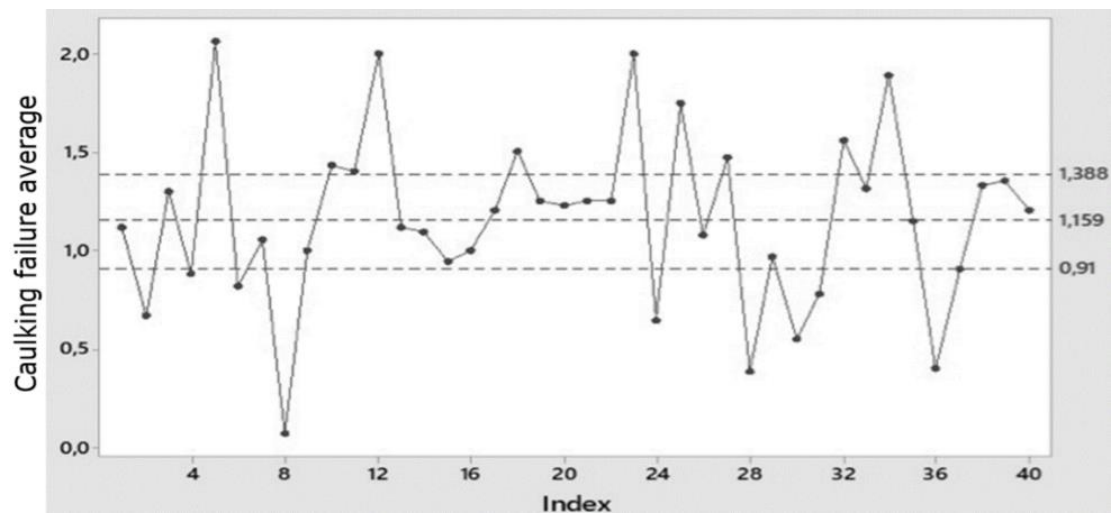

Figure 8. Daily average of caulking failures - dispersion of collected sample values

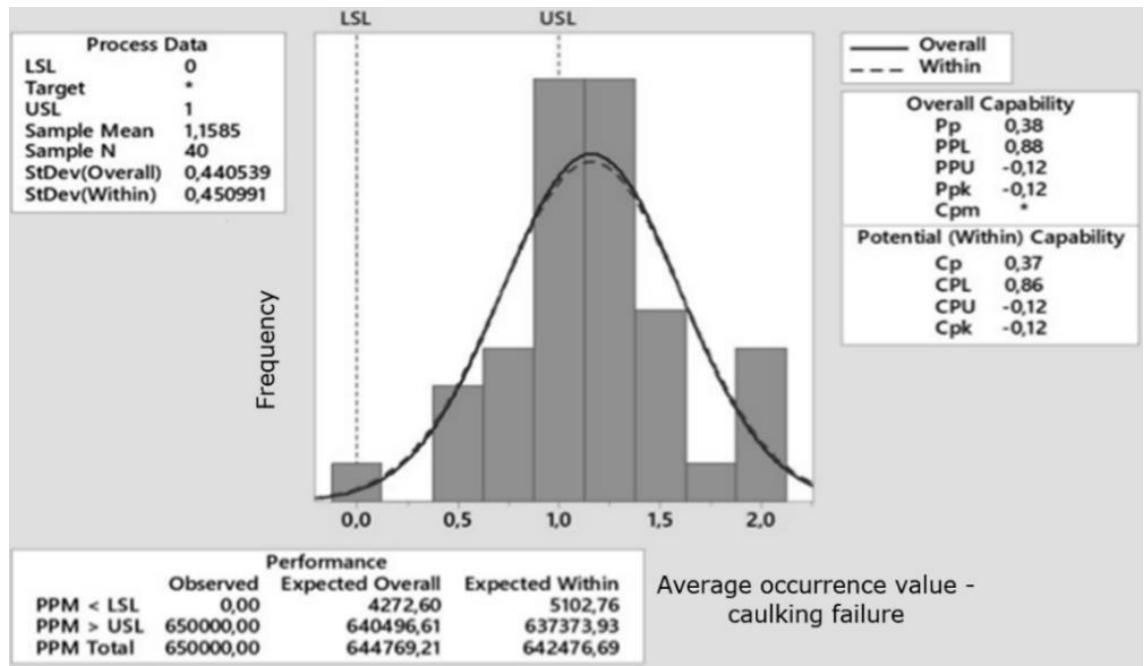

Figure 9. Initial process capability - caulking failure

The $\mathrm{C}_{\mathrm{p}}$ and $\mathrm{C}_{\mathrm{pk}}, \mathrm{P}_{\mathrm{p}}$ and $\mathrm{P}_{\mathrm{pk}}$ indices found indicate that the process has low capability and performance, and their values are below the established convention of 1.33 for $\mathrm{C}_{\mathrm{pk}}$ in automotive industries processes capability. Evaluation of the index calculation Inability process: $\mathrm{C}_{\mathrm{pk}}<1$ Acceptable process: $1=\mathrm{C}_{\mathrm{pk}}=$ 1.33 Capable process: $\mathrm{C}_{\mathrm{pk}}=1.33$.
The goal for the improvement project was set according to the data collection and process capability scenario mapped. The company's aim is to reduce the average occurrence value from 1.159 to the 0.91 value found in the first quartile, in order to meet the specification of 1.00 occurrence per vehicle established by the company. This change means a reduction of $21 \%$ in vehicle occurrences. 


\section{Result and Discussions}

Once we defined the problem to be treated and its current configuration with regard to incidences and impacts were established, the quality tools Cause and Effect Diagram, Ishikawa and Effort vs. Impact Matrix were used to assist in the search for the origin of the problem and to organize the solution methods, which reflected in positive results for the problem to reach the goal of 0.91 occurrence per vehicle. Therefore, the sequence of application of quality tools becomes essential to achieve the objectives of the work, so that the application of one tool triggers the need for the other since the detection of potential causes, the prioritization of causes, and the established action plan.

The improvement process started with the participation of the process engineering, industrial engineering and Kaizen units of the company through a brainstorming meeting to raise potential causes for the emergence of vehicle painting failures.

The ideas of all the collaborators involved were presented in a table so that it was possible to apply the Cause and Effect Diagram tool (Figure 10). A quality tool widely used to manage and control processes, that allows the analysis and identification of the main causes or occurrences of a problem, hence providing an overview of the subject under study (Prashar, 2018).

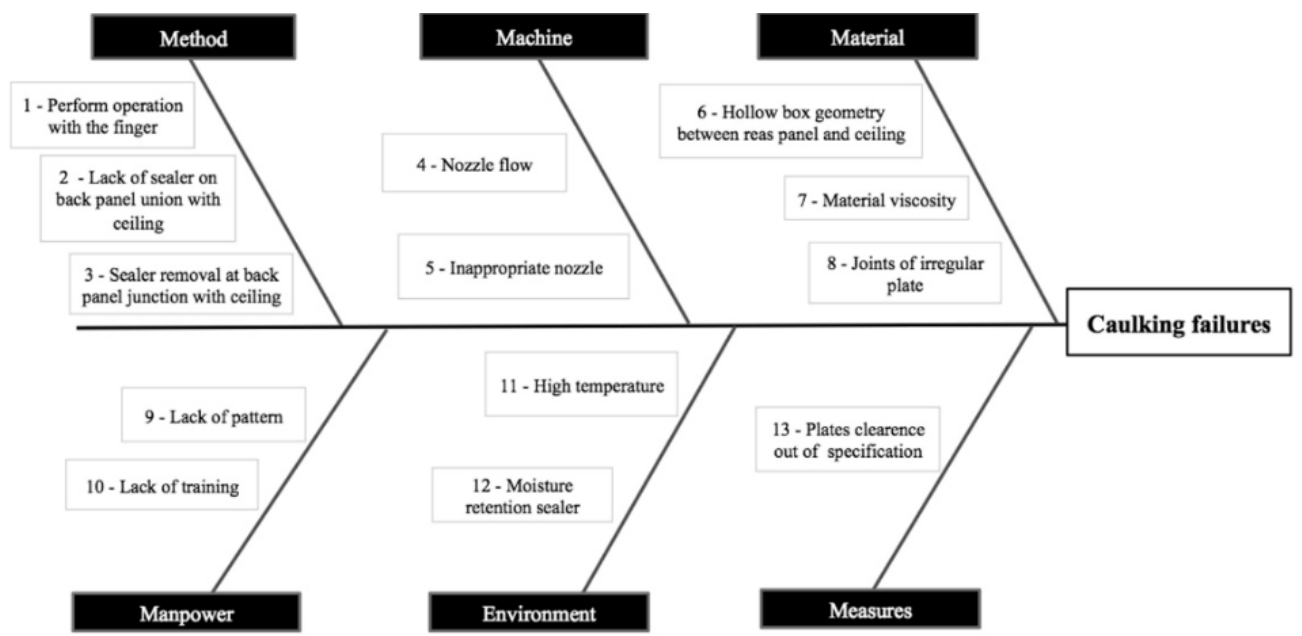

Figure 10. Cause and effect diagram for caulking failures

Once the cause and effect diagram was structured, a new brainstorming with the same team was performed to apply the Effort vs. Impact Matrix tool (Figure 11) based on caulking failures in Figure 10. The team could analyze, vote and select from the potential causes identified previously the ones that influence in a direct manner the product and then prioritize what emergency action plan will be prepared. This means that the Effort $\mathrm{x}$ Impact Matrix tool helps to narrow down the direct causes for optimizing work effort.
Using the Matrix tool (Figure 11) of Effort/Cost versus Impact, based on the previous Cause and Effect diagram (Figure 10) it was found the potential causes related to the appearance of the caulking failure in the vehicle that will have more impact and will demand less effort and cost, bottom right quadrant. According to matrix results they are: (01) perform operation with the finger; (03) removing the sealer at the junction of the rear panel with the vehicle roof; (02) lack of sealer in the rear panel region with the roof, (09) lack of pattern. 
From the problems that were selected, an action plan was developed using the $5 \mathrm{~W} 2 \mathrm{H}$ tool (Table 1), in order to prioritize the probable constrained causes.

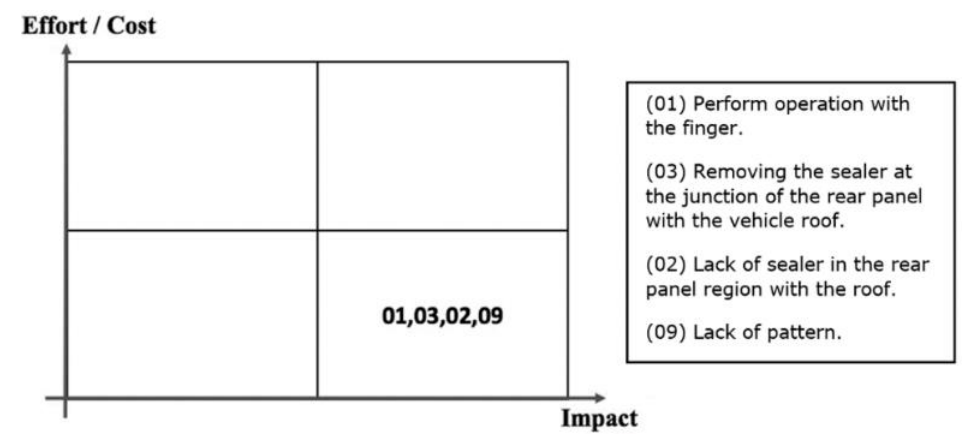

Figure 11. Effort/Cost vs. Impact Matrix of potential causes based on Cause and Effect diagram for caulking failures

Table 1. Action plan based on 5W1H tool

\begin{tabular}{|c|c|c|c|c|c|}
\hline \multicolumn{5}{|c|}{$5 \mathrm{~W}$} & \multirow{2}{*}{$\begin{array}{c}\text { 1H } \\
\text { How? }\end{array}$} \\
\hline What? & Why & Where? & Who? & When? & \\
\hline $\begin{array}{c}\text { Test } 1 / 2 " \\
\text { brush to } \\
\text { finish off the } \\
\text { sealer. }\end{array}$ & $\begin{array}{l}\text { Prevent the } \\
\text { emergence of } \\
\text { failures caused by } \\
\text { the use of the } \\
\text { operator's finger and } \\
\text { excessive removal of } \\
\text { material. }\end{array}$ & $\begin{array}{l}\text { Workstation } \\
5\end{array}$ & $\begin{array}{c}\text { Engineering } \\
\text { assistant }\end{array}$ & $12 / 26 / 2017$ & $\begin{array}{l}\text { Request the } \\
\text { operator to use } \\
\text { the tool and } \\
\text { monitor the cab. }\end{array}$ \\
\hline $\begin{array}{l}\text { Test PU } \\
\text { plate to } \\
\text { finish. }\end{array}$ & $\begin{array}{c}\text { Avoid the } \\
\text { appearance of } \\
\text { failures caused by } \\
\text { the use of the } \\
\text { operator's finger and } \\
\text { by the excessive } \\
\text { removal of material. }\end{array}$ & $\begin{array}{c}\text { Workstation } \\
5\end{array}$ & Intern & $12 / 27 / 2019$ & $\begin{array}{l}\text { Request the } \\
\text { operator to use } \\
\text { the plate and } \\
\text { monitor the cab } \\
\text { results. }\end{array}$ \\
\hline $\begin{array}{l}\text { Test mastic } \\
\text { glue on } \\
\text { stamping } \\
\text { marks. }\end{array}$ & $\begin{array}{c}\text { Avoid the } \\
\text { appearance of } \\
\text { failures caused by } \\
\text { the use of the } \\
\text { operator's finger and } \\
\text { by the excessive } \\
\text { removal of material. }\end{array}$ & $\begin{array}{l}\text { Workstation } \\
5\end{array}$ & Engineer & $12 / 28 / 2017$ & $\begin{array}{l}\text { Request the } \\
\text { operator to use } \\
\text { the trowel and } \\
\text { monitor the } \\
\text { cabin results. }\end{array}$ \\
\hline $\begin{array}{c}\text { Apply sealer } \\
\text { on stamping } \\
\text { marks. }\end{array}$ & $\begin{array}{l}\text { Avoid lack of sealer } \\
\text { in specific cab } \\
\text { regions. }\end{array}$ & $\begin{array}{c}\text { Workstation } \\
5\end{array}$ & Intern & $12 / 28 / 2017$ & $\begin{array}{l}\text { Modify sealer } \\
\text { application } \\
\text { method. }\end{array}$ \\
\hline $\begin{array}{l}\text { Implement } \\
\text { new work } \\
\text { pattern. }\end{array}$ & $\begin{array}{l}\text { Avoid operational } \\
\text { errors and guide the } \\
\text { activity to be } \\
\text { performed in the } \\
\text { same way. }\end{array}$ & $\begin{array}{c}\text { Workstation } \\
5\end{array}$ & $\begin{array}{c}\text { Engineering } \\
\text { assistant }\end{array}$ & $12 / 29 / 2017$ & $\begin{array}{l}\text { Instruct the } \\
\text { operator and } \\
\text { document the } \\
\text { sequence to be } \\
\text { performed. }\end{array}$ \\
\hline
\end{tabular}

Hugo O. G. Silva, M. C. M. Costa, M. V. C. Aguilera, M. G. D. Almeida, B. B. Fonseca, 
The application of the tool pointed out that the root cause of the caulking failure occurrence was related to the caulking operation using the finger as a way of finishing, which, besides being an act that presents risks of accidents to the operator, had a direct impact on service quality due to excessive removal of material from the application region (Ferreira, Santos \& Silva, 2019; Bravi, Murmura $\&$ Santos, 2019b).

Therefore, the action taken to reduce the indicators linked to the occurrence was the implementation of a $1 / 2$ " inch brush for finishing purpose, in addition to the elaboration of a new work pattern in the station, making the operation safer and more reliable.

After implementing the process improvement solution, satisfactory results were achieved with the use of the $1 / 2$ " inch brush, and the process indicators were positively impacted reaching the quality standards required by the company. Table 2 shows short-term operational data collected, as well as the statistical results achieved over the long term.

Table 2. Short-term results

\begin{tabular}{|c|c|c|c|c|}
\hline$\#$ & $\begin{array}{c}\text { Total of caulking } \\
\text { failures }\end{array}$ & Total vehicles & $\begin{array}{c}\text { Average of defective } \\
\text { cabins }\end{array}$ & Method \\
\hline I & 0 & 13 & $0 \%$ & Brush \\
\hline II & 4 & 12 & $33 \%$ & Finger \\
\hline III & 12 & 18 & $67 \%$ & Finger \\
\hline IV & 2 & 8 & $25 \%$ & Brush \\
\hline V & 0 & 5 & $0 \%$ & Brush \\
\hline VI & 3 & 13 & $23 \%$ & Brush \\
\hline VII & 10 & 27 & $37 \%$ & Finger \\
\hline VIII & 4 & 13 & $31 \%$ & Brush \\
\hline IX & 8 & 16 & $50 \%$ & Finger \\
\hline
\end{tabular}

Based on the operators' job rotation, a sample was collected to verify the errors related to the finishing methods and it was concluded that the use of the brush reduces the risk of vehicle caulking failure.

To verify the effectiveness of the proposed action, a statistical survey of the process behavior was performed (see Figures 12 and 13) one month after the implementation of the new way of doing the activity and new work pattern to relate new values obtained to the initial values collected, according to the results shown below.

Therefore, as shown in the final result, it obtained a higher than expected gain of $32.53 \%$, with the average below the target value 0.91 being the current average 0.782 , also reducing the standard deviation of the caulking process by $36.73 \%$ from 0.441 to 0.279 . Furthermore, the daily averages of caulking failure after implementation of improvements lead to better process control (Figure 14).

When discussing the capacity of a process, it is necessary to analyze the associated $\mathrm{C}_{\mathrm{pk}}$ and $\mathrm{C}_{\mathrm{pk}}$ indices. The capability of the company's caulking process has changed since the $\mathrm{C}_{\mathrm{p}}$ and $\mathrm{C}_{\mathrm{pk}}$ indices were increased to 0.79 and 0.35 , respectively, the process provides greater capacity and performance. However, the index values obtained are below the considered ideal value of 1.33 . Therefore, in the case where $\mathrm{C}_{\mathrm{pk}}<\mathrm{C}_{\mathrm{p}}$, as presented in this paper, the process is non-centered. Note that the condition $\mathrm{C}_{\mathrm{pk}}>\mathrm{C}_{\mathrm{p}}$ is impossible, since the value of $C_{p}$ is the maximum capability that a process can present. 


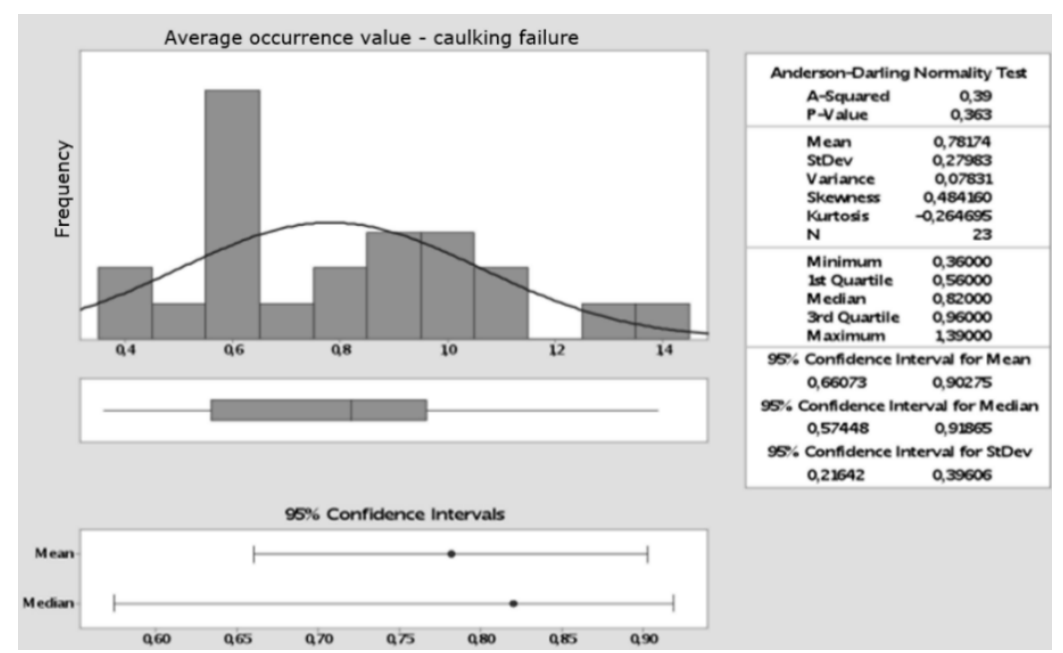

Figure 12. Sample collected and statistical results after the implementation of improvement actions

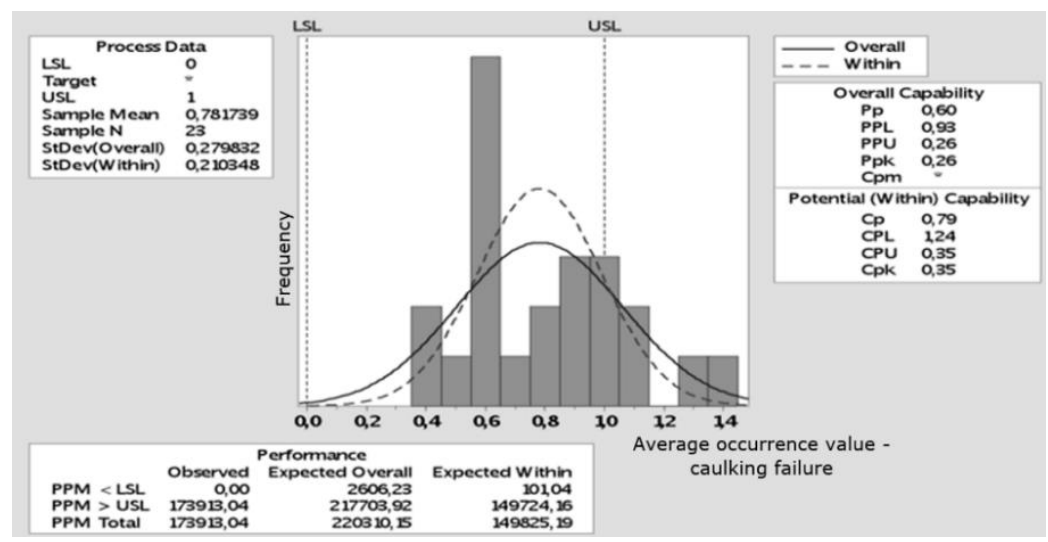

Figure 13. Process capability achieved

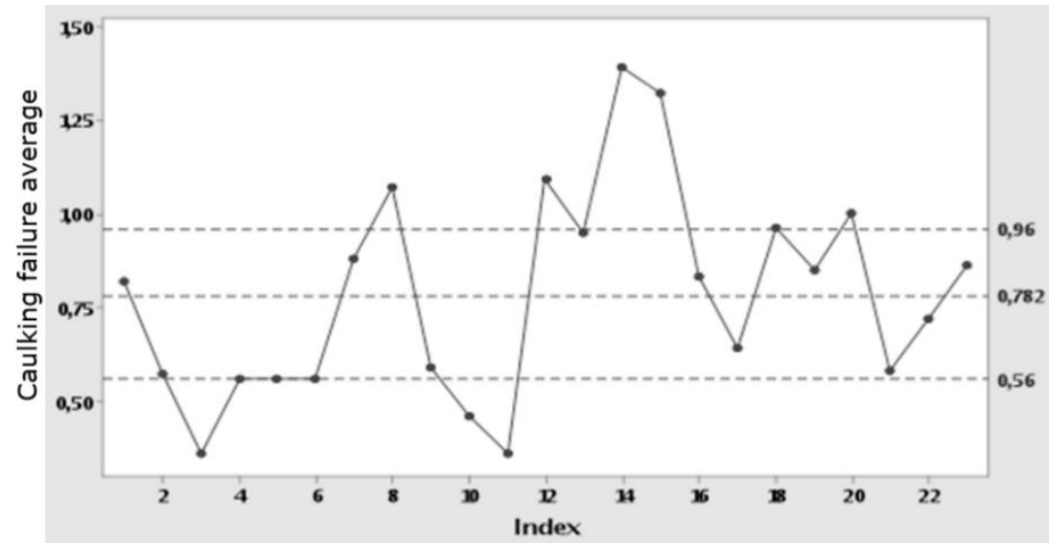

Figure 14. Daily averages of caulking failures after implementation of improvement actions 
The $\mathrm{C}_{\mathrm{p}}$ compares the specified tolerance with the potential variation of the process and describes the relationship between the space available for variation according to the specifications and the space occupied by the process variation. The $\mathrm{C}_{\mathrm{pk}}$ performance index, which takes into account the distance from the process average in relation to the specification limits. When the process operates centered on the nominal (target of the specification), the two indexes $\left(\mathrm{C}_{\mathrm{p}}\right.$ and $\mathrm{C}_{\mathrm{pk}}$ ) will have the same value, or very close values. As the average of the process deviates from the nominal, the $\mathrm{C}_{\mathrm{pk}}$ becomes smaller than the $\mathrm{C}_{\mathrm{p}}$ (Liu \& Li, 2020; Weusten \& Tummers, 2017; Wu, Lee, \& Chang Chien, 2017).

The interpretation of $\mathrm{C}_{\mathrm{p}}$ and $\mathrm{C}_{\mathrm{pk}}$ values depends on whether the process is under or out of statistical control, so if the process is under control, the $\mathrm{C}_{\mathrm{p}}$ and $\mathrm{C}_{\mathrm{pk}}$ represent the real capacity of the process - how it has behaved in the past and what is expected that you continue to do in the future. If the process is unpredictable - or out of control - $\mathrm{C}_{\mathrm{p}}$ and $\mathrm{C}_{\mathrm{pk}}$ are not representative, thus, the proximity between the values of $\mathrm{C}_{\mathrm{p}}$ and $\mathrm{C}_{\mathrm{pk}}$ characterizes a process that is being operated consistently over time. When these two indices differ substantially, you can be sure that the process is being operated in an unpredictable manner.

Montgomery (2017) defines the process is incapable when $C_{p}<1$, which is the case of the process studied in this work, and during the same discussion there was a need for higher levels of caulking of the paint, which did not occur fully but aroused the need to use medium and amplitude control graphics to improve the capacity of the process.

Another important aspect was the implementation of a new way of performing the activity. This change had a positive impact on the painting process with a reduction in the risk of vehicle caulking failure and reduction in the risk of accident. However, as pointed out by Fin et al. (2017), to maintain the work standardized, it is important to constantly check any change in the process that may modify the operations performed. In addition, the company should consider changes in the product, enabling process improvements and acquire new tools and devices to data and personnel involved are always up to date.

\section{Conclusion}

According to the results obtained in this study it can be concluded that the increased of the $\mathrm{C}_{\mathrm{p}}$ and $\mathrm{C}_{\mathrm{pk}}$ indices in the caulking process capability provided a better capacity and performance, despite the index values were lower than the ideal values.

One alternative that the company can apply to achieve higher $\mathrm{C}_{\mathrm{p}}$ and $\mathrm{C}_{\mathrm{pk}}$ values is to use the average and amplitude control charts to detect variability in both indices. Thus, the average is taken to the center, which results in greater process capability.

The study points to the need for consistency of work in search of higher indexes and, consequently, greater capability of the caulking process. Caulking is a critical step in vehicle painting and has a direct impact on the end customer of the product. As a manual process that requires attention, the caulking process requires skill and dexterity from the operator; the proposed actions resulted in improvement of vehicle production and better conditions for operators with the simple implementation of a new brush, which made the operation safer and more reliable.

This study was limited to conduct a data collection and analysis using statistical process control tools not considering aspects such as the moment when the failure occurs during the work shift, the operator's experience time and the production demand. Future research could, for instance, considered such aspects, which will contribute to understand the process in detailed in order to develop improvement actions to the identified failures including the different elements of the system. 
Acknowledgment: This study was funded in part by the Coordenação de Aperfeiçoamento de Pessoal de Nível Superior - Brazil (CAPES).

\section{References:}

Africano, N., Rodrigues, A. S., \& Santos, G. (2019).The main benefits of the implementation of the quality management system in higher education institutions in Angola. Quality Innovation Prosperity, 23(3), 122-136.

Araujo, R., Santos, G., Costa, J. B., \& Sá, J.C. (2019). The Quality Management System as a Driver of Organizational Culture: An Empirical Study in the Portuguese Textile Industry. Quality Innovation Prosperity, 23(1), 1-24.

Azevedo, J., Sá, J. C., Ferreira, L. P., Santos, G., Cruz, F. M., Jimenez, G., \& Silva, F. J. G. (2019). Improvement of production line in the automotive industry through lean philosophy. Procedia Manufacturing, 41,1023-1030.

Barbosa, L. C. F. ., de Oliveira, O. J., \& Santos, G. (2018). Proposition for the alignment of the integrated management system (quality, environmental and safety) with the business strategy. International Journal for Quality Research, 12(4), 925-940. https://doi.org/10.18421/IJQR12.04-09

Barbosa, L. C. F. M., Mathias, M. A. S., Santos, G., \& de Oliveira, O. J. (2020). How the knowledge of the major researchers is forging the business strategy paths: Trends and forecasts from the state of the art. Quality Innovation Prosperity, 24(3), 1-20.

Bravi, L., Murmura, F., \& Santos, G. (2019a). The ISO 9001:2015 quality management system standard: Companies' drivers, benefits and barriers to its implementation. Quality Innovation Prosperity, 23(2), 64-82.

Bravi, L., Murmura, F., \& Santos, G. (2019b). Additive manufacturing: Possible problems with indoor air quality. Procedia Manufacturing, 41, 952-959

Capizzi, G. (2015). Recent Advances in Process Monitoring: Nonparametric and VariableSelection Methods for Phase I and Phase II. Quality Engineering, 27(1), 44-67. https://doi.org/10.1080/08982112.2015.968046

Carvalho, F., Santos, G., \& Gonçalves, J. (2019). Critical analysis of information about integrated management systems and environmental policy on the Portuguese firms' website, towards sustainable development. Corporate Social Responsibility and Environmental Management, 27, 1069-1088.

Chan, L.-K., \& Wu, M.-L. (2002). Quality Function Deployment: A Comprehensive Review of Its Concepts and Methods. Quality Engineering, 15(1), 23-35. https://doi.org/10.1081/QEN120006708

Costa, A. R., Barbosa, C., Santos, G., \& Rui Alves, M. (2019). Six sigma: Main metrics and r based software for training purposes and practical industrial quality control. Quality Innovation Prosperity, 23(2), 83-100. doi: 10.12776/QIP.V23I2.1278.

Deleryd, M. (1999). A pragmatic view on process capability studies. International Journal of Production Economics, 58(3), 319-330. https://doi.org/10.1016/S0925-5273(98)00214-X

Escobar, C. A., Wincek, M. A., Chakraborty, D., \& Morales-Menendez, R. (2018). ProcessMonitoring-for-Quality-Applications. Manufacturing Letters, 16, 14-17. https://doi.org/10.1016/j.mfglet.2018.02.004 
Félix, M. J., Silva, S., Santos, G., Doiro, M., \& Sá, J. $\quad$ C., $\quad$ (2019a). Integrated product and processes development in design: A case study. Procedia Manufacturing, 41, 296-303. DOI: 10.1016/j.promfg.2019.09.012.

Félix, M. J., Gonçalves, S., Jimenez, G., \& Santos, G. (2019b). The contribution of design to the development of products and manufacturing processes in the Portuguese industry. Procedia Manufacturing, 41,1055-1062. DOI: 10.1016/j.promfg.2019.10.033.

Ferreira, N., Santos, G., \& Silva, R. (2019). Risk level reduction in construction sites: Towards a computer aided methodology - A case study. Applied Computing and Informatics, 15, 136143. DOI: 10.1016/j.aci.2018.01.003.

Fin, J. C., Vidor, G., Cecconello, I., \& Machado, V. D. C. (2017). Improvement based on standardized work: an implementation case study. Brazilian Journal of Operations \& Production Management, 14(3), 388. https://doi.org/10.14488/BJOPM.2017.v14.n3.a12

Jimenez, G., Santos, G., Sá, J. C., Ricardo, S., Pulido, J., Pizarro, A., \& Hernández, H. (2019). Improvement of productivity and quality in the value chain through lean manufacturing - A case study. Procedia Manufacturing, 41, 882-889. DOI: 10.1016/j.promfg.2019.10.011

Liu, G., \& Li, W. (2020). New dynamic reliability assessment method based on process capability index and fault importance index. Quality Engineering, 1-17. https://doi.org/10.1080/08982112.2020.1754428

Machado, A. B., Silva, F. J. G., Sá, J. C., Barreiras, A., Ferreira, L. P., Pereira, M. T., \& Santos, G. (2020). Improvement in External Logistics of an Automative Component Manufacturing Company Towards Costs Reduction. International Journal for Quality Research, 14(4),11751190. DOI: 10.24874/IJQR14.04-12.

Mehrafrooz, Z., \& Noorossana, R. (2011). An integrated model based on statistical process control and maintenance. Computers \& Industrial Engineering, 61(4), 1245-1255. https://doi.org/10.1016/j.cie.2011.07.017

Montgomery, D. C. (2017). Design and Analysis of Experiments. Wiley $\left(9^{\circ}\right)$. Danvers: Wiley.

Murmura, F., Bravi, L., \& Santos, G. (2021). Sustainable process and product innovation in the eyewear sector: The role of industry 4.0 enabling technologies. Sustainability, 13(1), 1-17. DOI: $10.3390 / \mathrm{su} 13010365$.

Nunhes, T. V., Motta Barbosa, L. C. F., \& de Oliveira, O. J. (2017). Identification and analysis of the elements and functions integrable in integrated management systems. Journal of Cleaner Production, 142, 3225-3235. https://doi.org/10.1016/j.jclepro.2016.10.147

Prashar, A. (2018). Toward cycle time reduction in manufacturing SMEs: Proposal and $\begin{array}{llll}\text { evaluation. } & \text { Quality } & \text { Engineering, } & \text { 30(3), }\end{array}$ https://doi.org/10.1080/08982112.2018.1460669

Rasay, H., Naderkhani, F., \& Golmohammadi, A. M. (2020). Designing variable sampling plans based on lifetime performance index under failure censoring reliability tests. Quality Engineering, 32(3), 354-370. https://doi.org/10.1080/08982112.2020.1754426

Rebelo, M. F., Santos, G., \& Silva, R. (2016). Integration of management systems: towards a sustained success and development of organizations. Journal of Cleaner Production, 127, 96111

Ribeiro, P., Sá, J. C., Ferreira, L. P., Silva, F. J. G., Pereira, M. T., \& Santos, G. (2019). The Impact of the Application of Lean Tools for Improvement of Process in a Plastic Company: a case study. Procedia Manufacturing, 38,765-775. DOI:10.1016/j.promfg.2020.01.104. 
Rodrigues, J., Sá, J. C. V., Ferreira, L. P., Silva, F. J. G., \& Santos, G. (2019). Lean Management "Quick-Wins": Results of Implementation. A Case Study. Quality Innovation Prosperity, 23(3),3-21. DOI: 10.12776/qip.v23i3.1291.

Rodrigues, J., Sá, J. C., Silva, F. J. G., Ferreira, L. P., Jimenez, G., \& Santos, G. (2020). A rapid improvement process through "quick-win" lean tools: A case study. Systems, 8(4), 119

Rungtusanatham, M. (2001). Beyond improved quality: the motivational effects of statistical process control. Journal of Operations Management, 19(6), 653-673. https://doi.org/10.1016/S0272-6963(01)00070-5

Sá, J. C., Vaz, S., Carvalho, O., Morgado, L., Lima V., Fonseca, L., Doiro, M., \& Santos, G. (2020). A model of integration ISO 9001 with Lean six sigma and main benefits achieved. Total Quality Management \& Business Excellence, in press. DOI: $10.1080 / 14783363.2020 .1829969$.

Santos, G., Mendes, F., \& Barbosa, J. (2011). Certification and integration of management systems: the experience of Portuguese small and medium enterprises. Journal of Cleaner Production, 19, 1965-1974.

Santos, G., Rebelo, M., Barros, S., Silva, R., Pereira, M., Ramos, G., \& Lopes, N. (2014). Developments regarding the integration of the occupational safety and health with quality and environment management systems. Occupational Safety and Health, 113-146

Santos, G., Mandado, E., Silva, R., \& Doiro, M. (2019 $)$. Engineering learning objectives and computer assisted tools. European Journal of Engineering Education, 44(4), 616-628. DOI: 10.1080/03043797.2018.1563585.

Santos, G., Sá, J. C., de Oliveira, J., Ramos, D. G., \& Ferreira, C. (2019b). Quality and safety continuous improvement through lean tools. In: F.J.G. Silva and L.C.P. Ferreira, ed. 2019. Lean Manufacturing: Implementation, Opportunities and Challenges. New York: Nova Science Publishers. pp.165-188.

Santos, G., Gomes, S., Braga, V., Braga, A., Lima, V., Teixeira, P., \& Sá, J.C. (2019c). Value creation through quality and innovation - a case study on Portugal. TQM Journal, 31(6), 928947. DOI: 10.1108/TQM-12-2018-0223.

Santos, G., Murmura, F., \& Bravi, L. (2019). Developing a model of vendor rating to manage quality in the supply chain. International Journal of Quality and Service Sciences, 11(1), pp.34-52. DOI: 10.1108/IJQSS-06-2017-0058.

Santos, G., Doiro, M., Félix, M. J., Mandado, E., Sá, J. C., Gonçalves, J., \& Teixeira, P. (2020). On the concept of an integrated and lean model of product development proposed for intellectual property creation and competitive economies. International Journal of Intellectual Property Management, 10(4), 409-435.

Schippers, W. A. J. (1998). Applicability of statistical process control techniques. International Journal of Production Economics, 56-57, 525-535. https://doi.org/10.1016/S09255273(98)00054-1

Silva, A., Sá, J.C., Santos, G., Silva, F. J. G., Ferreira, L. P., \& Pereira, M. T. (2020). Implementation of SMED in a cutting line. Procedia Manufacturing, 51, 1355-1362

Stylidis, K., Madrid, J., Wickman, C., \& Söderberg, R. (2017). Towards Overcoming the Boundaries between Manufacturing and Perceived Quality: An Example of Automotive Industry. Procedia CIRP, 63, 733-738. https://doi.org/10.1016/j.procir.2017.03.091

Hugo O. G. Silva, M. C. M. Costa, M. V. C. Aguilera, M. G. D. Almeida, B. B. Fonseca, 
Tsung, F., Zhang, K., Cheng, L., \& Song, Z. (2018). Statistical transfer learning: A review and some extensions to statistical process control. Quality Engineering, 30(1), 115-128. https://doi.org/10.1080/08982112.2017.1373810

Vieira, T., Sá, J.C., Lopes, M.P., Santos, G., Félix, M.J., Ferreira, L.P., Silva, F.J.G. and Pereira, M.T. (2019). Optimization of the cold profiling process through SMED. Procedia Manufacturing, 38, 892-899. DOI: 10.1016/j.promfg.2020.01.171.

Wagner, I. T., Gomes e Silva, J. N., Alencar, V. R., de Souza Sampaio, N. A., de Araujo Junior, A. H., de Barros, J. G. M., \& da Fonseca, B. B. (2019). Ergonomic Analysis on the Assembly Line of Home Appliance Company (pp. 116-123). https://doi.org/10.1007/978-3-319-960685_13

Weusten, J. J. A. M., \& Tummers, P. H. G. (2017). Process capability in industry: Setting preliminary statistical specification limits. Quality Engineering, 29(4), 713-718. https://doi.org/10.1080/08982112.2016.1265650

White, K., Szarka, J., Childress, A., \& Jensen, W. (2020). A recommended set of indices for evaluating process health. Quality Engineering, 1-12. https://doi.org/10.1080/08982112.2020.1787442

Wu, C.-W., Lee, A. H. I., \& Chang Chien, C.-C. (2017). A variables multiple dependent state sampling plan based on a one-sided capability index. Quality Engineering, 29(4), 719-729. https://doi.org/10.1080/08982112.2017.1288913

Wu, C.-W., Pearn, W. L., \& Kotz, S. (2009). An overview of theory and practice on process capability indices for quality assurance. International Journal of Production Economics, 117(2), 338-359. https://doi.org/10.1016/j.ijpe.2008.11.008

Yin, R. K. (2017). Case study research: design and methods. SAGE Publications (6o). Thousand Oaks: SAGE Publications.

Zgodavova, K., Bober, P., Majstorovic, V., Monkova, K., Santos, G., \& Juhaszova, D. (2020). Innovative methods for small mixed batches production system improvement: The case of a bakery machine manufacturer. Sustainability, 12(15), 1-20. 
Hugo de Oliveira

Guimarães da Silva

Universidade do Estado do Rio de Janeiro,

Resende,

Brazil

hugo.osilva@hotmail.com

Maria da Glória Diniz de Almeida

Universidade do Estado do Rio de Janeiro,

Resende,

Brazil

gloria uerj@yahoo.com.br

\section{Luís César Ferreira Motta} Barbosa

Centro Federal de Educação

Tecnológica Celso Suckow da

Fonseca,

Rio de Janeiro,

Brazil

$\underline{\text { luiscesarfmb@gmail.com }}$

\section{Mariana Cristina}

Magalhães Costa

Universidade do Estado do Rio de Janeiro,

Resende,

Brazil

marianacmcosta@hotmail.com

Bernardo Bastos da

Fonseca

Universidade do Estado do Rio de Janeiro,

Resende,

Brazil

bernardobastosf@gmail.com

\section{Gilberto Santos}

ESD - Polytechnic Institute of

Cavado and Ave,

Barcelos,

Portugal

gsantos@ipca.pt

\section{Maria Victoria}

Cabrera Aguilera

Universidade do Estado do

Rio de Janeiro,

Resende,

Brazil

mvca85@gmail.com

\section{José Salvador da Motta}

Reis

Universidade Estadual

Paulista,

Guaratnguetá,

Brazil

jmottareis@gmail.com

\section{Nilo Antonio de Souza \\ Sampaio}

Universidade do Estado do

Rio de Janeiro,

Resende,

Brazil

nilo.samp@terra.com.br 